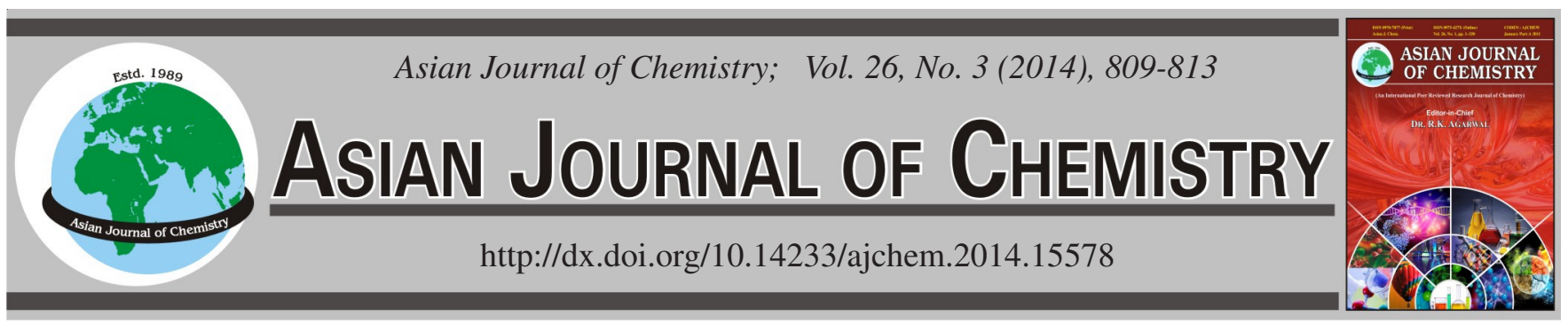

\title{
Fluorimetric Determination of Trace Bisphenol-A Based on its Oxidative Reaction with Fenton-Like Reagent as Oxidant
}

\author{
JiAnting Wang, JiAn Zhang, Jun Zhu and RenMin Gong*
}

College of Life Science, Anhui Normal University, Wuhu, 241000, P.R. China

*Corresponding author: Tel: +86 553 5991085; E-mail: rmgong.nju@163.com

\begin{abstract}
Bisphenol-A (BPA) is an exogenous substance that acts like hormones in the endocrine system and disrupts the physiologic function of endogenous hormones. Due to the widespread human exposure to bisphenol-A and its potential adverse effects on human health, special attention has been paid to the determination of bisphenol-A in the environment. In this paper, a simple, sensitive and selective fluorimetric method for the determination of bisphenol-A, based on the oxidative reaction of bisphenol-A in the presence of hydrochloric acid by Fenton-like reagent $\left(\mathrm{Fe}^{3+}+\mathrm{H}_{2} \mathrm{O}_{2}\right)$, had been developed. The fluorescence came from the oxidation product of bisphenol-A at $\lambda_{\text {excitation }} 315$ and $\lambda_{\text {emission }} 415 \mathrm{~nm}$ in $\mathrm{pH} 8.90$ Tris- $\mathrm{HCl}$ buffer solution. Under the optimum conditions, a linear relationship had been obtained between the fluorescence intensity and the concentration of bisphenol-A in the range of $0.01-0.5 \mu \mathrm{g} / \mathrm{mL}$, with detection limit and correlation coefficient being $0.64 \mathrm{ng} / \mathrm{mL}$ and 0.9995 , respectively. The proposed method had been successfully applied for the determination of trace bisphenol-A in water, beverage bottle and cling wrap film.
\end{abstract}

Keywords: Fluorimetric determination, Bisphenol-A, Fenton-like reagent and oxidative reaction.

\section{INTRODUCTION}

Endocrine disrupting compounds (EDCs) are exogenous substances that act like hormones in the endocrine system and disrupt the physiological function of endogenous hormones. Among various problems caused by endocrine disrupting compounds, the pollution of phenolic endocrine disrupting compounds in environmental water has aroused the public concerns as these contaminants were frequently detected in different water sources in recent years ${ }^{1,2}$. Bisphenol-A (BPA), a phenolic endocrine disrupting compound, has been widely used as the monomeric substance for the production of polycarbonate and epoxyphenolic resins and as the stabilizer or antioxidant for many types of plastics ${ }^{3}$. Due to the widespread human exposure to BPA and its potential adverse effects on human health, special attention has been paid to the determination of BPA in the environment. Various methods such as high-performance liquid chromatography (HPLC) ${ }^{4-6}$, liquid chromatographymass spectrometry (LC-MS $)^{7-9}$, gas chromatography-mass spectrometry (GC-MS) ${ }^{10-12}$, fluorimetry ${ }^{13,14}$ and electrochemical analysis $^{15,16}$, have been reported for the determination of BPA. However, some of these methods are expensive, time consuming and need skilful technicians and sometimes require enrichment ${ }^{17,18}$ and extraction steps ${ }^{19,20}$ that increase the risk of sample loss.
Bisphenol-A shows intrinsic fluorescence in different organic solvents but its fluorescence intensity in aqueous solution is too low to be directly determined ${ }^{21}$. Our studies showed that BPA could be oxidized by Fenton-like reagent in the medium of dilute hydrochloric acid, the oxidation product of BPA emitted strong natural fluorescence in $\mathrm{pH} 8.90$ Tris$\mathrm{HCl}$ buffer solution and the fluorescence intensity was linearly related to the concentration of BPA. Based on this new discovery, an inexpensive, sensitive and selective method of fluorimetry had been proposed for the determination of BPA. To our best knowledge, no literatures are available concerning the determination of trace BPA based on the fluorescence signal of its oxidation product. The proposed method had been successfully applied to the determination of BPA in real samples.

\section{EXPERIMENTAL}

All chemicals were of analytical reagent grade or the best grade commercially available and double distilled water was used throughout. Standard stock solution of bisphenol-A $(0.200 \mathrm{mg} / \mathrm{mL})$ was prepared by dissolving $0.100 \mathrm{~g}$ of solid BPA in $0.5 \mathrm{~mL}$ of $0.1 \mathrm{~g} / \mathrm{mL}(\mathrm{w} / \mathrm{v})$ sodium hydroxide solution, then diluting in $500 \mathrm{~mL}$ volumetric flask with water and stored in the dark at $4{ }^{\circ} \mathrm{C}$. Working BPA solutions were obtained by diluting the stock solution to the required concentration. 
Standard Fe(III) stock solution $(0.10 \mathrm{mg} / \mathrm{mL})$ was obtained by dissolving $0.2420 \mathrm{~g}$ of solid $\mathrm{FeCl}_{3} \cdot 6 \mathrm{H}_{2} \mathrm{O}$ in water and diluting to $500 \mathrm{~mL}$ in a volumetric flask. Working $\mathrm{Fe}(\mathrm{III})$ solutions were freshly prepared by appropriate dilution of the stock solution. Other chemical solutions used during the study include: $0.005 \%$ hydrogen peroxide solution, $0.008 \mathrm{~mol} / \mathrm{L}$ hydrochloric acid and $0.1 \mathrm{~mol} / \mathrm{L}$ Tris- $\mathrm{HCl}$ buffer solution ( $\mathrm{pH} 8.9)$.

The fluorescence spectra and fluorescence intensities were recorded on a Shimadzu RF-5301 spectrofluorometer equipped with a xenon lamp and $1 \mathrm{~cm}$ quartz cells. Slit widths of both monochromator were set at $10 \mathrm{~nm}$, unless otherwise noted. A Model 501 thermostat bath (Chongqing, China) was used to control reaction temperatures.

Sample processing: The environmental water samples were filtrated and the filtrates were passed through the anion exchange resin (Strong-base OH form, Xi' an, China), cation exchange resin (Strong-acid H form, Xi' an, China) and XDA1 adsorption resin (Xi'an, China) orderly in the pH 3.0, then the leachates were adjust to $\mathrm{pH} 7$ for analysis.

The beverage bottle were washed with water, solarized and cut into pieces of $0.5 \mathrm{~cm}^{2}$. An appropriate amount of sample was put in a conical flask and $100 \mathrm{~mL}$ of water was added. A given amount of the cling wrap film was cut into pieces and put in a conical flask and $100 \mathrm{~mL}$ of water was added. The solutions were heated in a water bath $\left(90.0 \pm 0.2^{\circ} \mathrm{C}\right)$ for $2 \mathrm{~h}$ and then cooled to room temperature.

Procedure: An appropriate amount of standard or sample solution containing 0.25-12.5 $\mu \mathrm{g}$ BPA was transferred to a $25 \mathrm{~mL}$ colorimetric tube and then the following reagents were added successively: $0.5 \mathrm{~mL}$ of $0.4 \mu \mathrm{g} / \mathrm{mL} \mathrm{Fe}(\mathrm{III}), 1 \mathrm{~mL}$ of $0.005 \%$ hydrogen peroxide, $1 \mathrm{~mL}$ of $0.008 \mathrm{~mol} / \mathrm{L}$ hydrochloric acid. The mixture was diluted to $10 \mathrm{~mL}$ with water and mixed completely. The colorimetric tube was heated in a thermostatted water bath $\left(90 \pm 0.2^{\circ} \mathrm{C}\right)$ for $8 \mathrm{~min}$ and cooled to room temperature by running water. Then the mixture was diluted to the mark with $0.1 \mathrm{~mol} / \mathrm{L}$ Tris- $\mathrm{HCl}$ buffer solution $(\mathrm{pH} 8.90)$ and mixed thoroughly. After $10 \mathrm{~min}$, the fluorescence intensity of the mixture solution was measured at excitation and emission wavelengths of 315 and $415 \mathrm{~nm}$, respectively. The fluorescence intensity of a reagent blank solution without BPA was similarly measured under the same conditions.

\section{RESULTS AND DISCUSSION}

Spectral characteristics: According to the proposed procedure, the excitation and emission spectra of BPA oxidation product were measured. Fig. 1 showed that the maximum emission wavelength of BPA oxidation product was $415 \mathrm{~nm}$ with the excitation wavelength at $315 \mathrm{~nm}$. Furthermore, it was observed that there was a linear relationship between the fluorescence intensity $\left(\mathrm{F}-\mathrm{F}_{0}\right)$ and the concentration of BPA in the system.

Effects of the medium and concentration: The following media had been tried in the present experiments: sulfuric acid, phosphoric acid, nitric acid and hydrochloric acid. It was found that in sulfuric acid and phosphoric acid, the sensitivity of the reaction was very low, but in nitric acid, the sensitivity of the reaction was high but with poor stability. In hydrochloric acid, the sensitivity and stability of the reaction were both satisfactory.
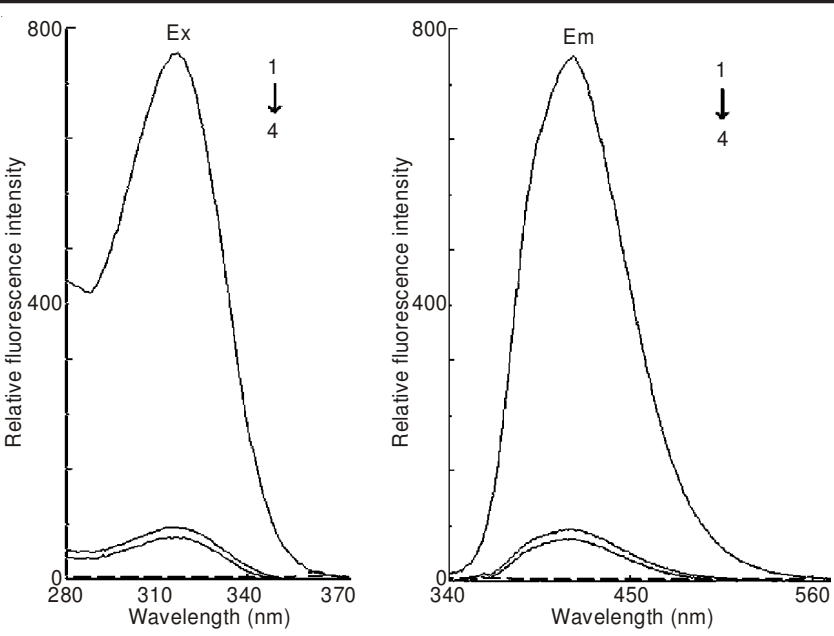

Fig. 1. Excitation (Ex) and emission (Em) spectra of BPA oxidation product: (1) BPA- $\mathrm{H}_{2} \mathrm{O}_{2}-\mathrm{Fe}(\mathrm{III})-\mathrm{HCl} / \mathrm{Tris}-\mathrm{HCl}$ buffer, (2) $\mathrm{BPA}-\mathrm{H}_{2} \mathrm{O}_{2}$ $\mathrm{HCl} /$ Tris-HCl buffer, (3) BPA-Fe(III)-HCl/Tris-HCl buffer, (4)BPA$\mathrm{HCl} /$ Tris- $\mathrm{HCl}$ buffer systems. [BPA]: $0.4 \mu \mathrm{g} / \mathrm{mL},\left[\mathrm{H}_{2} \mathrm{O}_{2}\right]: 2 \times 10^{-4}$ $\%,[\mathrm{Fe}(\mathrm{III})]: 8 \mathrm{ng} / \mathrm{mL},[\mathrm{HCl}]: 0.32 \mathrm{mmol} / \mathrm{L}$, buffer $\mathrm{pH}$ value: 8.9 , temperature: $90^{\circ} \mathrm{C}$, time: $8 \mathrm{~min}$

The influence of hydrochloric acid concentration was studied in the range of $0.08-0.56 \mathrm{mmol} / \mathrm{L}$. As could be seen from Fig. 2, the fluorescence intensity increased by increasing the hydrochloric acid concentration to $0.32 \mathrm{mmol} / \mathrm{L}$ and then decreased. Because Fe(III) can only remain stable in acidic solution, the oxidative reaction of BPA must be carried out in acidic medium. However, when the $\mathrm{pH}$ value is very low, the excess $\mathrm{H}^{+}$ quenches the produced peroxyl radicals. It causes a decrease in the fluorescence intensity. Therefore, a final concentration of $0.32 \mathrm{mmol} / \mathrm{L}$ hydrochloric acid was selected as optimum condition.

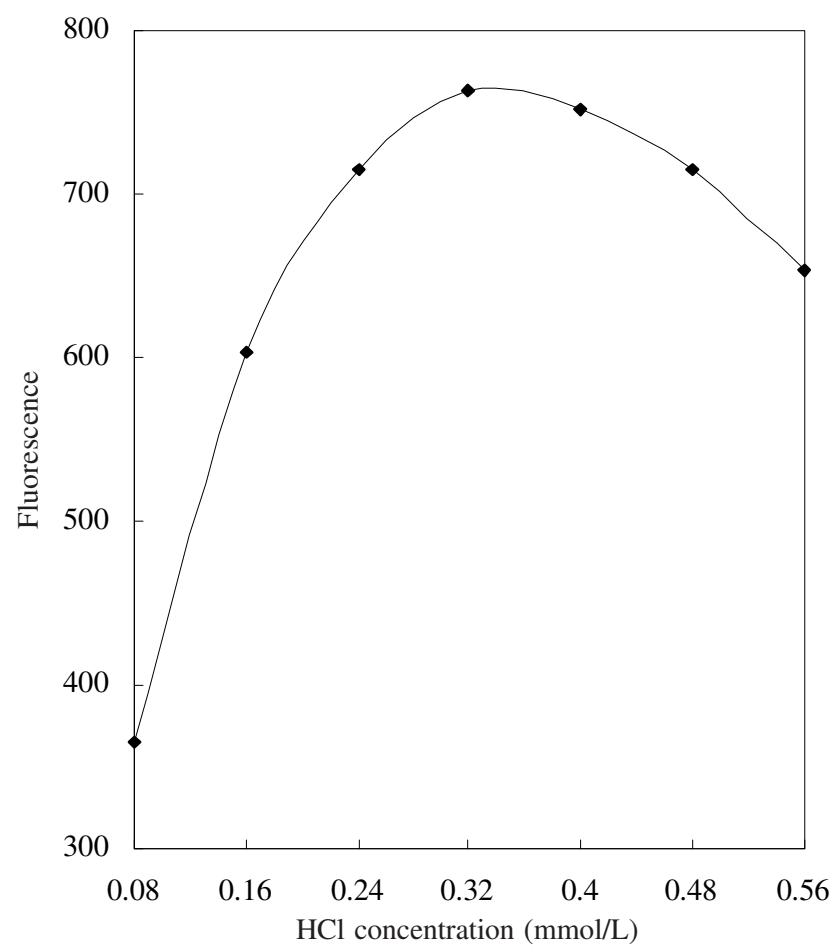

Fig. 2. Effect of $\mathrm{HCl}$ concentration on fluorescence signal ([BPA]: $0.4 \mu \mathrm{g}$ / $\mathrm{mL},\left[\mathrm{H}_{2} \mathrm{O}_{2}\right]: 2 \times 10^{-4} \%$, [Fe(III)]: $8 \mathrm{ng} / \mathrm{mL}$, buffer $\mathrm{pH}$ value: 8.9 , temperature: $90{ }^{\circ} \mathrm{C}$, time: $8 \mathrm{~min}$ ) 
Effects of $\mathbf{p H}$ and buffers: It is observed that the fluorescence intensity of BPA oxidation product increased significantly by changing acidic medium to basic medium. So the following buffer solutions had been tested in the present experiments: phosphate buffer solution, carbonate buffer solution, borate buffer solution and Tris- $\mathrm{HCl}$ buffer solution. The Tris-HCl buffer solution was found to be best among the above buffer solutions. It could be seen from Fig. 3 that the highest fluorescence signal was obtained in $\mathrm{pH} 8.90$ Tris- $\mathrm{HCl}$ buffer solution. The similar result was reported in literature ${ }^{22}$.

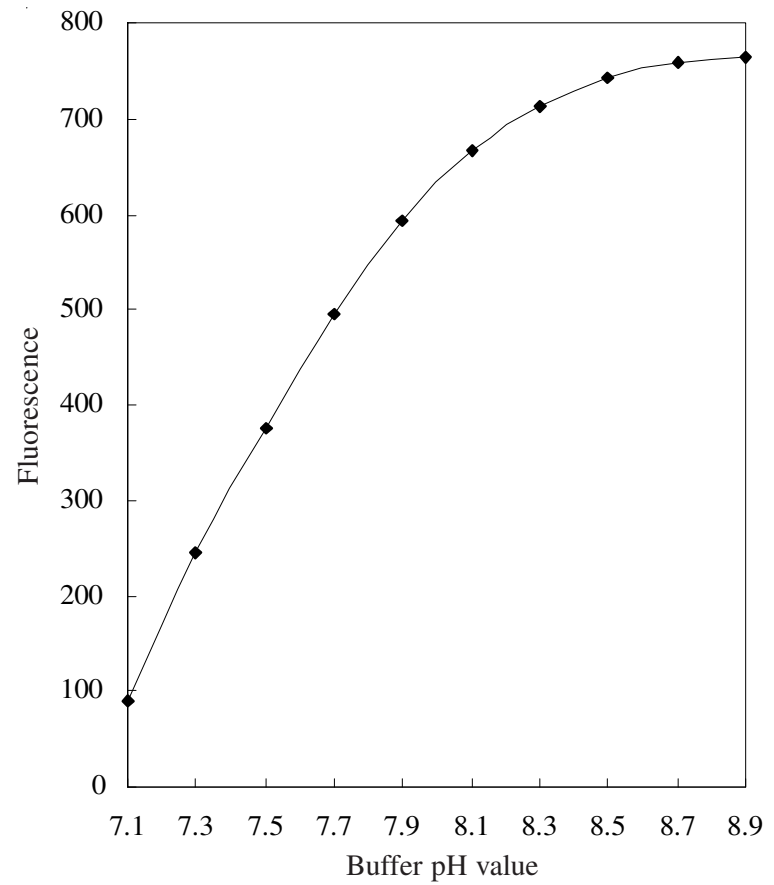

Fig. 3. Effect of buffer $\mathrm{pH}$ value on fluorescence signal ([BPA]: $0.4 \mu \mathrm{g} /$ $\mathrm{mL},\left[\mathrm{H}_{2} \mathrm{O}_{2}\right]: 2 \times 10^{-4} \%$, [Fe(III)]: $8 \mathrm{ng} / \mathrm{mL},[\mathrm{HCl}]: 0.32 \mathrm{mmol} / \mathrm{L}$, temperature: $90^{\circ} \mathrm{C}$, time: $8 \mathrm{~min}$ )

Effects of $\mathrm{H}_{2} \mathrm{O}_{2}$ and $\mathrm{Fe}$ (III) concentration: As the precursor of the hydroxyl radicals, the concentration of $\mathrm{H}_{2} \mathrm{O}_{2}$ affects the oxidation of BPA. The effect of the $\mathrm{H}_{2} \mathrm{O}_{2}$ concentration on the oxidation of BPA was investigated in the range of 0.4-3.2 $\times 10^{-4} \% \mathrm{H}_{2} \mathrm{O}_{2}$ and the result was shown in Fig. 4. It was found that when the $\mathrm{H}_{2} \mathrm{O}_{2}$ concentration was lower than $2 \times 10^{-4} \%$, the fluorescence intensity increased rapidly with the increase of $\mathrm{H}_{2} \mathrm{O}_{2}$ concentration, then the fluorescence intensity had a slight decrease with the further increase of the $\mathrm{H}_{2} \mathrm{O}_{2}$ concentration.

The effect of $\mathrm{Fe}(\mathrm{III})$ concentration on the oxidation of BPA was shown Fig. 5. It was observed that the fluorescence intensity increased with the increase of Fe(III) concentration up to $8 \mathrm{ng} / \mathrm{mL}$ and then decreased with the further increase of the Fe(III) concentration. Because Fe(III) is used as the initial oxidant in the redox system, its concentration greatly influences peroxyl radicals generated. So final concentrations of $2 \times 10^{-4}$ $\% \mathrm{H}_{2} \mathrm{O}_{2}$ and $8 \mathrm{ng} / \mathrm{mL} \mathrm{Fe}$ (III) were selected as optimum condition.

Effects of reaction temperature and time: The effects of the reaction temperature and time on the oxidation of BPA were investigated in the range of $30-100{ }^{\circ} \mathrm{C}$ for $2-14 \mathrm{~min}$, respectively. The effect of temperature on the oxidation of BPA was illustrated in Fig. 6. It could be seen that the fluorescence

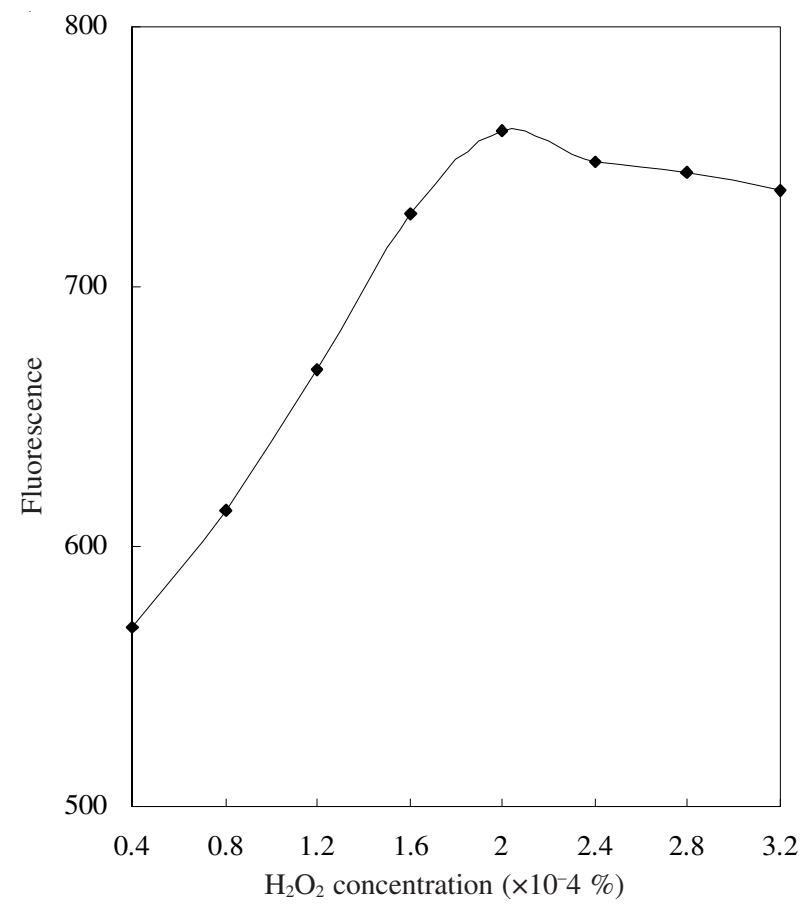

Fig. 4. Effect of $\mathrm{H}_{2} \mathrm{O}_{2}$ concentration on fluorescence signal ([BPA]: 0.4 $\mu \mathrm{g} / \mathrm{mL},[\mathrm{Fe}(\mathrm{III})]: 8 \mathrm{ng} / \mathrm{mL},[\mathrm{HCl}]: 0.32 \mathrm{mmol} / \mathrm{L}$, buffer $\mathrm{pH}$ value: 8.9 , temperature: $90^{\circ} \mathrm{C}$, time: $8 \mathrm{~min}$ )

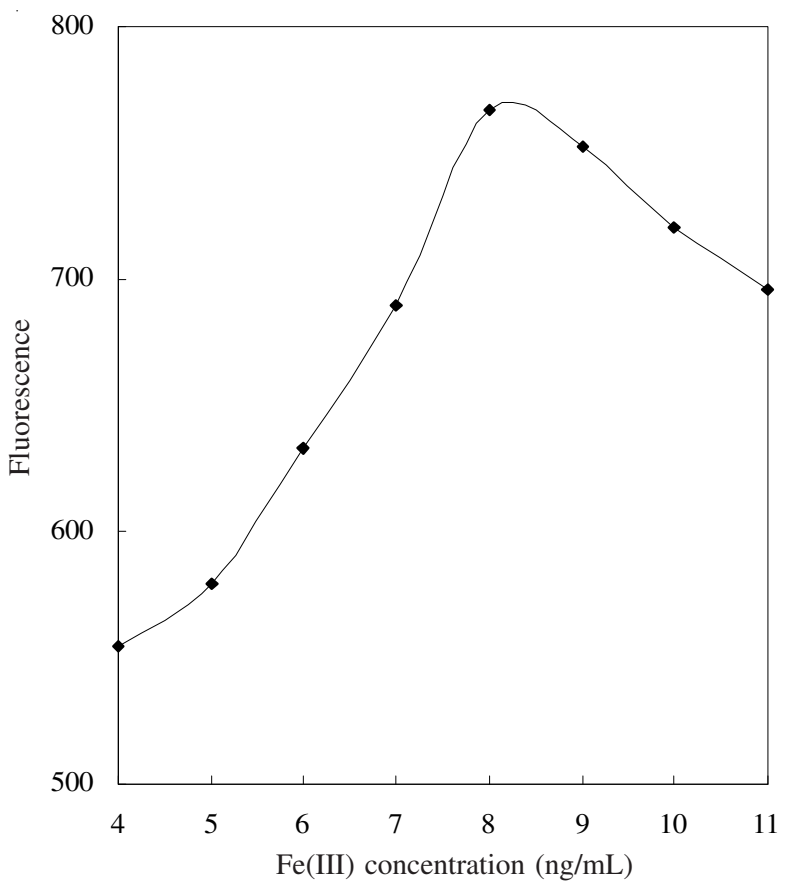

Fig. 5. Effect of $\mathrm{Fe}$ (III) concentration on fluorescence signal ([BPA]: 0.4 $\mu \mathrm{g} / \mathrm{mL},\left[\mathrm{H}_{2} \mathrm{O}_{2}\right]: 2 \times 10^{-4} \%$, [HCl]: $0.32 \mathrm{mmol} / \mathrm{L}$, buffer $\mathrm{pH}$ value: 8.9, temperature: $90^{\circ} \mathrm{C}$, time: $8 \mathrm{~min}$ )

intensity increased with increasing temperature up to $90{ }^{\circ} \mathrm{C}$. But the fluorescence intensity decreased at the temperature above $90{ }^{\circ} \mathrm{C}$.

Fig. 7 showed that the fluorescence intensity increased with prolonging reaction time in the range of 2-8 min, but the fluorescence intensity decreased in longer reaction time. Thus, $90{ }^{\circ} \mathrm{C}$ and $8 \mathrm{~min}$ were recommended as the best reaction temperature and time. Because the fluorescence compound may be decomposes in higher temperature and longer time. 


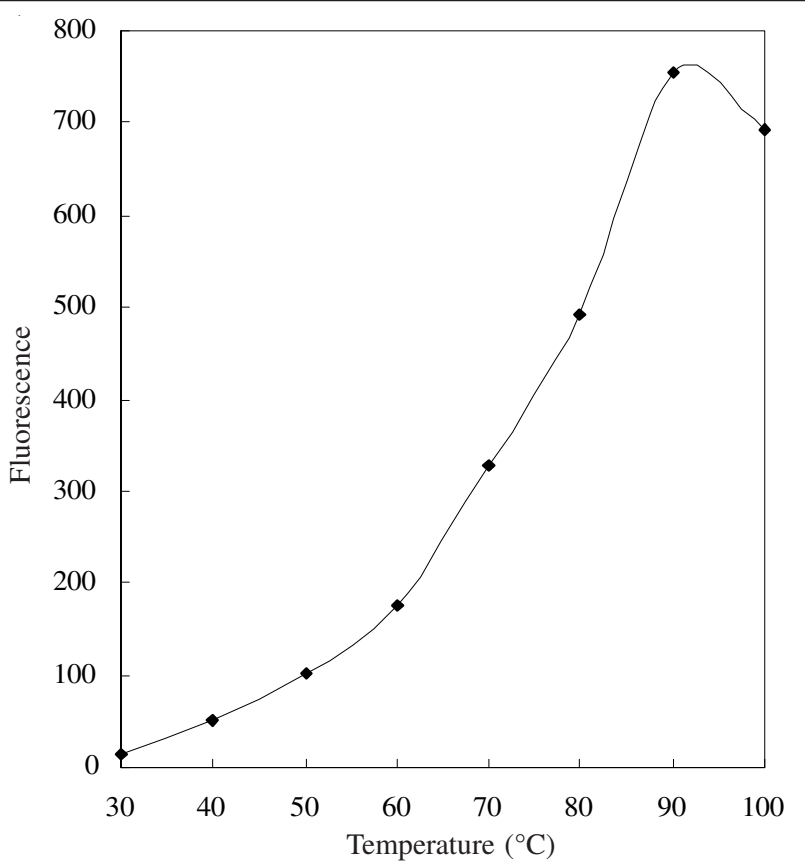

Fig. 6. Effect of temperature on fluorescence signal ([BPA]: $0.4 \mu \mathrm{g} / \mathrm{mL}$, $\left[\mathrm{H}_{2} \mathrm{O}_{2}\right]: 2 \times 10^{-4} \%,[\mathrm{Fe}(\mathrm{III})]: 8 \mathrm{ng} / \mathrm{mL},[\mathrm{HCl}]: 0.32 \mathrm{mmol} / \mathrm{L}$, buffer $\mathrm{pH}$ value: 8.9 , time: $8 \mathrm{~min}$ )

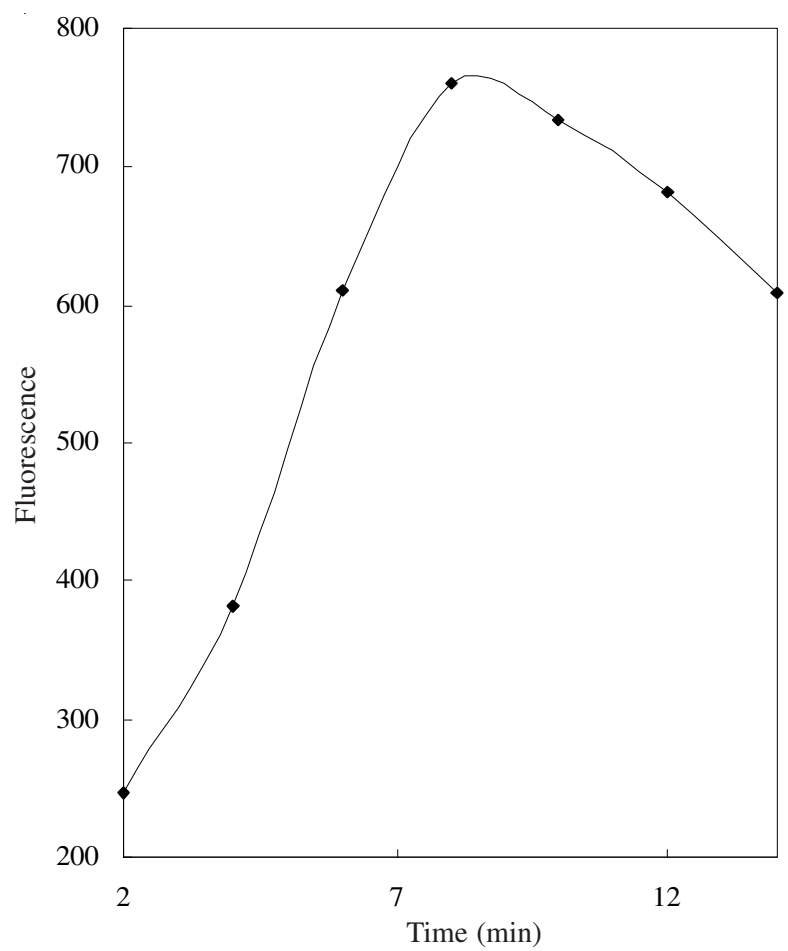

Fig. 7. Effect of time on fluorescence signal ([BPA]: $0.4 \mu \mathrm{g} / \mathrm{mL},\left[\mathrm{H}_{2} \mathrm{O}_{2}\right]: 2$ $\times 10^{-4} \%,[\mathrm{Fe}(\mathrm{III})]: 8 \mathrm{ng} / \mathrm{mL},[\mathrm{HCl}]: 0.32 \mathrm{mmol} / \mathrm{L}$, buffer $\mathrm{pH}$ value: 8.9 , temperature: $90^{\circ} \mathrm{C}$ )

Fluorimetric determination of BPA and the calibration curve: Based on the optimum conditions described above for the oxidation of BPA in the presence of hydrochloric acid by Fenton-like reagent, the new fluorimetric method for the determination of BPA was established. Under these optimum conditions, a linear relationship was obtained between the relative fluorescence intensity and the concentration of BPA in the range of 0.01 and $0.5 \mu \mathrm{g} / \mathrm{mL}$. The linear regression equa- tion of the calibration curve was $\Delta \mathrm{F}=1895.1 \mathrm{C}_{(\mathrm{\mu g} / \mathrm{mL})}+3.9916$ ( $\Delta \mathrm{F}$ is the difference between relative fluorescence intensity of sample and blank and $\mathrm{C}$ is the concentration of BPA), with the correlation coefficient 0.9995 . The detection limit of the method $\left(3 \mathrm{~S}_{\mathrm{b}} / \mathrm{k}\right.$, three of the standard deviation blank divided by slope of the calibration curve) was $0.64 \mathrm{ng} / \mathrm{mL}$. It could be found that the proposed method had wider linear range and lower detection limit, compared with the fluorimetric method reported in literature ${ }^{14}$.

Effect of foreign substances: To study the selectivity of the proposed method, the interference of a series of foreign substances on the determination of $0.4 \mu \mathrm{g} / \mathrm{mL}$ BPA was investigated under the optimum conditions. The tolerance limit was defined as the concentration at which the species caused an error of less than $\pm 5 \%$. The interferences were listed in Table-1. The results demonstrated that except for some metal cations, citric acid, salicylic acid and phenolic compounds, most of the studied inorganic and organic substances did not interfere with the determination. However, the influences of metal cations, citric acid and salicylic acid could be completely removed by using a cation exchange resin of strong-acid $\mathrm{H}$ form and an anion exchange resin of strong-base $\mathrm{OH}$ form; through the research of synthetic samples, it was found that the interference of the other phenolic compounds could be effectively removed by XDA-1 adsorption resin (Xi' an, China) ${ }^{14}$. Therefore, the proposed method had good selectivity.

Practical application: To evaluate the analytical applicability of the method, the proposed method was applied to the determination of BPA in water and plastics samples. After being pre-separated to remove interferences, BPA in samples was determined directly and the results were given in Table- 2 . The recoveries for the samples determination were in $97-105 \%$ with relative standard deviation less than $3.2 \%$, which indicated that there was no serious interference through the proposed sample preparation.

\section{Conclusion}

Combined the traditional Fenton oxidation technique with sensitive fluorimetric method, a new spectrofluorimetry had been proposed for the determination of BPA, a phenolic endocrine disrupting compound. By pre-separating with ionic exchange resins and adsorption resin, the BPA in samples could be determined directly at $\mathrm{ng} / \mathrm{mL}$ levels with the recoveries between 97 and $105 \%$ in all the cases. Compared with the fluorimetric methods reported in literatures ${ }^{13,14}$, its operation procedure was simple, fast and convenient. In comparison with the conventional determination method, the proposed method also was rapid, inexpensive, simple for operation and easy of popularization. But for acquiring accurate result, the determination procedure must be controlled under the optimum conditions.

\section{ACKNOWLEDGEMENTS}

The authors gratefully acknowledged the financial support of this study by the Key Laboratory of Bioresource Protection and Utilization of Anhui Province, the Key Laboratory of Biotic Environment and Ecological Safety of Anhui Province and the Key Science Research Item of Anhui Normal University. 


\begin{tabular}{lccc}
\hline \multicolumn{5}{c}{ TABLE-1 } \\
\multicolumn{4}{c}{ EFFECT OF FOREIGN SUBSTANCES ON THE DETERMINATION OF BISPHENOL-A } \\
\hline \multicolumn{1}{c}{ Foreign substance } & Tolerance ratio & \multicolumn{1}{c}{ Substance } & Tolerance ratio \\
\hline $\mathrm{Na}^{+}, \mathrm{K}^{+}, \mathrm{NH}_{4}^{+}, \mathrm{Ca}^{2+}, \mathrm{Mg}^{2+}, \mathrm{Cl}^{-}$ & $>1000$ & $\mathrm{CO}_{3}{ }^{2-}, \mathrm{HCO}_{3}{ }^{-}, \mathrm{HPO}_{4}{ }^{2-}, \mathrm{H}_{2} \mathrm{PO}_{4}{ }^{-}$ & $>500$ \\
$\mathrm{SO}_{4}{ }^{2-}, \mathrm{PO}_{4}{ }^{3-}, \mathrm{NO}_{3}^{-}, \mathrm{Zn}^{2+}, \mathrm{Cd}^{2+}$ & $>200$ & $\mathrm{Al}^{3+}, \mathrm{Ba}^{2+}$, sucrose, fructose & $>100$ \\
$\mathrm{SO}_{3}{ }^{2-}, \mathrm{Sn}^{2+}, \mathrm{Br}^{-}$, dextrose & $>50$ & $\mathrm{Cr}^{3+}, \mathrm{Ni}^{2+}, \mathrm{Co}^{2+}, \mathrm{Cu}^{2+}, \mathrm{Mn}^{2+}$ & $>10$ \\
$\mathrm{Hg}^{2+}, \mathrm{Pb}^{2+}$, citric acid & $>5$ & $\mathrm{Salicylic}^{2+}$ acid, nitrophenol, phenol & $<1$ \\
\hline
\end{tabular}

\begin{tabular}{|c|c|c|c|c|c|}
\hline \multirow{3}{*}{ Sample } & \multicolumn{4}{|c|}{$\begin{array}{c}\text { TABLE-2 } \\
\text { RESULTS OF BISPHENOL-A DETERMINATION IN REAL WATER SAMPLES }(n=5)\end{array}$} & \\
\hline & \multicolumn{5}{|c|}{ BPA } \\
\hline & Added $(\mu \mathrm{g} / \mathrm{mL})$ & Found $(\mu \mathrm{g} / \mathrm{mL})$ & Recovery (\%) & $\operatorname{RSD}(\%)$ & Found in sample \\
\hline \multirow{2}{*}{ Tap water } & 0 & 0 & - & - & \multirow{2}{*}{0} \\
\hline & 0.1 & 0.098 & 98 & 2.25 & \\
\hline \multirow{2}{*}{ Wastewater } & 0 & 0.12 & - & 2.71 & \multirow{2}{*}{0.5} \\
\hline & 0.1 & 0.225 & 105 & 3.18 & \\
\hline \multirow{2}{*}{ Beverage bottle } & 0 & 0.023 & - & 1.87 & \multirow{2}{*}{0.958} \\
\hline & 0.1 & 0.125 & 102 & 2.69 & \\
\hline \multirow{2}{*}{ Cling wrap film } & 0 & 0.012 & - & 1.44 & \multirow{2}{*}{1.25} \\
\hline & 0.1 & 0.109 & 97 & 2.19 & \\
\hline
\end{tabular}

\section{REFERENCES}

1. C. Desbrow, E.J. Routledge, G.C. Brighty, J.P. Sumpter and M. Waldock, Environ. Sci. Technol., 32, 1549 (1998).

2. A. Laganà, A. Bacaloni, I. De Leva, A. Faberi, G. Fago and A. Marino, Anal. Chim. Acta, 501, 79 (2004).

3. C.A. Staples, P.B. Dome, G.M. Klecka, S.T. Oblock and L.R. Harris, Chemosphere, 36, 2149 (1998).

4. Y. Cai, G. Jian, J. Liu and Q. Zhou, Anal. Chem., 75, 2517 (2003).

5. L. Grumetto, D. Montesano, S. Seccia, S. Albrizio and F. Barbato, J. Agric. Food Chem., 56, 10633 (2008).

6. M. Rezaee, Y. Yamini, S. Shariati, A. Esrafili and M. Shamsipur, $J$. Chromatog. A, 1216, 1511 (2009).

7. H. Sambe, K. Hoshina, K. Hosoya and J. Haginaka, J. Chromatogr. A, 1134, 16 (2006).

8. N.C. Maragou, E.N. Lampi, N.S. Thomaidis and M.A. Koupparis, J. Chromatogr. A, 1129, 165 (2006).

9. W. Yan, Y. Li, L. Zhao and J. Lin, J. Chromatogr. A, 1216, 7539 (2009).

10. R.J.W. Meesters and H.F. Schröder, Anal. Chem., 74, 3566 (2002).

11. N. Casajuana and S. Lacorte, J. Agric. Food Chem., 52, 3702 (2004).
12. C. Sánchez-Brunete, E. Miguel and J.L. Tadeo, J. Chromatogr. A, 1216, 5497 (2009).

13. M.D. Olmo, A. Zafra, A.B. Jurado and J.L.Vilchez, Talanta, 50, 1141 (2000).

14. J. Fan, H. Guo, G. Liu and P. Peng, Anal. Chim. Acta, 585, 134 (2007).

15. H. Yin, L. Cui, S. Ai, H. Fan and L. Zhu, Electrochim. Acta, 55, 603 (2010).

16. J.-H. Li, D.-Z. Kuang, Y.-L. Feng, F.-X. Zhang and M.-Q. Liu, Asian J. Chem., 25, 3147 (2013).

17. A. Motoyama, A. Suzuki, O. Shirota and R. Namba, Rapid Commun. Mass Sp., 13, 2204 (1999).

18. J. Liu, X. Liang, G. Jiang, Y. Cai, Q. Zhou and G. Liu, Talanta, 60, 1155 (2003).

19. S. Nakamura and S. Daishima, J. Chromatogr. A, 1038, 291 (2004).

20. A. Moral, M.D. Sicilia, S. Rubio and D. Pérez-Bendito, J. Chromatogr. A, 1100, 8 (2005).

21. M.D. Olmo, A. Zafra, A. Gonzalez-Casado and J.L. Vilchez, Int. J. Environ. Anal. Chem., 69, 99 (1998).

22. J. Gao, J. Zhou and X. Qu, Anal. Sci., 21, 409 (2005). 